\title{
THE IRONIES OF MANDATORY PLACEMENT
}

\author{
Craig Hadden \\ Lamar Community College, Lamar, Colorado, USA
}

\begin{abstract}
Despite the efforts of the past decade to prepare students for the rigors of college course work, higher education continues to find that a high percentage of students need varying degrees of remediation to help them succeed in college courses. Most, if not all, community colleges conduct placement testing to assess student skills in reading, writing, and mathematics and sometimes for study skills and learning styles. However, the dilemma arises concerning the appropriate action to take once underprepared students are identified-requiring mandatory placement in developmental classes or allowing them the right to fail. In Colorado, placement testing is mandatory, but students have the right to waive placement into developmental courses. The overarching dilemma involving mandatory placement rests at the heart of what community colleges pride themselves on most-the egalitarian position of open access and the effort to provide all students with the highest quality of education. This dilemma raises ethical issues as well as exposes a number of ironies, which this article explores: access versus success, course prerequisites for college-level courses, the junior-level writing requirement at the University of Colorado-Boulder, performance indicators in Colorado, a rising junior exam, self-esteem, the right to fail, egalitarianism, and context.
\end{abstract}

Mandatory placement may actually provide the key to opening the door to true academic, vocational, or community success despite the criticisms by some that it excludes students and restricts their freedoms.

Perhaps nowhere in community colleges do more ironies exist about an ethical course of action than in the issue of mandatory placement of underprepared students. The overarching dilemma rests at the heart of what community colleges pride themselves on most- the egalitarian position of open access and the effort to provide all students with the highest quality of education. The ethical dilemma that community colleges confront concerns what is in the best interest of students-not an easy issue when considering the diverse skills of community college students. A host of ethical issues relate to the underprepared student.

Address correspondence to Craig Hadden, Dean of Instruction and Assessment, Lamar Community College, 2401 South Main Street, Lamar, Colorado 81052, USA. E-mail: craig.hadden@ lcc.cccoes.edu 
Is it ethical to deny any student access to a class? Is mandatory placement discriminatory, especially to minority students? Is it ethical to allow underprepared students to fail? However, just as troubling is the issue of fairness to prepared students who may find themselves in classes in which the professor is moving at a slower rate or watering down the course material to help underprepared students pass the course. How ethical is it for faculty members try to maintain academic rigor when half the class is underprepared to succeed? One might even wonder how ethical it is for taxpayers to pay for underprepared students to enroll in courses which they ultimately fail. Unfortunately, as with all ethical issues, no right answer exists, but the issues certainly lead to a number of ironies concerning the question of mandatory placement for underprepared students.

\section{BACKGROUND}

The literature uses various terms to characterize the dilemma, including "access versus success" or "access versus standards" (Berger, 1997), "laissez-faire open access" versus "structured open access" (Fonte, 1997), and the "open door versus the revolving door" (Roueche, Baker, \& Roueche, 1984). Essentially, however, the conflict arises from trying to maintain academic standards to ensure the legitimacy of community colleges in the face of a philosophy that allows students at any skill level to enroll in a college-level course.

As Roueche and Roueche (1993) labeled it, this dilemma puts community colleges "between a rock and a hard place." One irony is that although open-access community colleges allow all students to enroll in college-level courses regardless of their skill level, they also allow a large number of students to fail. Mitchell (1989) characterizes the admittance of underprepared students into open-access programs as "committing the fraud of promising and charging for educational services that we could not deliver because we gave 'students the right to fail' and provided programs that all but ensured that they exercised that right" (p. 4). "Access" should not be confused with "success" for those students who enter college lacking basic reading, writing, mathematics, and study skills.

Dr. Dorothy Horrell, president of the Colorado Community College and Occupational Education System (CCCOES), summarized the dilemma for Colorado community colleges. "On the one hand, the research is persuasive in showing that students who test below college entry level, [sic] perform and persist better after successful remediation than students who do not complete the remediation. The other side of the debate is that our students are adults and should, 
after having been given appropriate advice and counseling, make their own decisions about whether to complete remediation." Horrell also hopes that the state can reduce the need for remediation for recent high school graduates by strengthening high school graduation standards and clearly communicating the skills students need to succeed in college-level courses (D. Horrell, personal communication, October 22, 1999). In the past few year, Colorado has undertaken a massive effort to create competency standards to guide the state's high schools in the hopes that they may eventually graduate students with college-level skills. However, a report from the Educational Support Services of the CCCOES indicates that this desire may be a while in coming. In addition, recent high school graduates are only part of the developmental mix of students.

According to the most recent CCCOES report profiling basic skills education, $18.2 \%$ of the student body was enrolled in at least one basic skills class in 1997-98. ${ }^{1}$ This percentage appears low but could more than double if students were not allowed to waive placement into developmental courses.

CCCOES began tracking and reporting these data in 1993. In its baseline report, students under 22 years old comprised $32.1 \%$ of the basic skills course headcount; according to the most recent report, this figure has risen to $42.9 \%$. These figures also indicate that approximately $57 \%$ of those enrolled in developmental courses are not recent high school graduates, so the hope that improving high school standards will eliminate the need for developmental studies is, perhaps, wishful thinking. Furthermore, regardless of how much high school student performance improves in the future, community colleges will always need to provide remediation for older students returning to college. Still, it would be unfair to blame Colorado high schools totally for this increase since only $48.9 \%$ of the total number enrolled in basic skills courses are Colorado high school graduates (36.9\% graduated out of state and $14.2 \%$ were unknown). However, the indications are that despite nationwide efforts to improve the basic skill level of high school graduates, high numbers of underprepared recent graduates are still enrolling in community colleges. Yet basic skills education is not limited to students under 22 . A total of $46.7 \%$

\footnotetext{
${ }^{1}$ These figures include 12 of the state's 16 community colleges. The 12 are part of the state system for community colleges governed by the State Board of Community Colleges and Occupational Education System (SBCCOES); since these figures were compiled, one of the remaining three local-district colleges in the state joined the state system. However, at the time the figures were compiled this college along with the state's two remaining local district colleges and its online community college were excluded from the figures.
} 
of the total student body enrolled in basic education courses are ages 22 to 39 (Zhou \& Voorhees, 1999). Furthermore, the $18.2 \%$ of the total 1997-98 headcount included only those students who consented to enroll in a basic skills class. Since state board policy requires mandatory placement testing but allows students to waive the placement advice, considerably more underprepared students are enrolling in the state's community colleges. Clearly, the need for developmental courses continues to exist. But in Colorado, when open access combines with a student's right to choose, the irony of access versus success becomes a reality.

Ultimately, access versus success places community colleges in a dilemma of choice and standards. Although the irony produced from trying to uphlold academic standards while providing open access constitutes the fundamental mandatory placement dilemma facing community colleges, it is by no means the only irony. Other ironies include course prerequisites for college-level courses, a junior-level writing requirement, performance indicators, a possible rising junior examination in Colorado, self-esteem, the right to fail, egalitarianism, and context.

\section{The Irony of Access versus Success}

Being egalitarian and providing opportunities for all students regardless of their abilities to succeed, community colleges create their own dilemma. On the one hand, community colleges want to promote student success, which means helping students progress to graduation, successful transfer, career, or self-improvement. Community colleges also value access because it means providing opportunity, which encourages and supports diversity (Bogart, 1994). However, this notion of access may cause conflict if people assume that access means open admission to any course and the student's right to choose. Cohen and Brawer (1996) note that the increasing failure rates at the end of the 1970s shifted the concerns of community colleges toward trying to retain students. When faced with increasing numbers of underprepared students entering the classroom combined with a desire to help students succeed, college faculty members are finding that expectations for student achievement have declined. "The weight of the low-ability student hangs like an anchor on the community colleges"' (p. 261). The authors also claim that teaching a class of students whose skills range from 3rd to 13th grade levels is demoralizing (p. 262). If the only definition of access is open admission, then this notion is incompatible with success without compromising standards. 
Rhoads and Valadez (1996) provide another definition for access. For them, access involves increasing a student's ability to participate in economic, political, and social institutions after leaving the community college. "To merely open the doors to students without any serious attempt at creating opportunities for their full participation in America's social life in all its forms is really not access at all" (p. 34). Therefore, using this concept of access, one might argue that open admission to a course for which a community college knows the student is underprepared and is likely to fail is denying that student access to advance in academics (transfer), career (vocational), or society (personal), which are the major roles of community colleges today. Therefore, what many think of as being access (open admission) is ironically not access at all without trying to ensure the students' success. Allowing students to enroll in a class for which they are underprepared under the pretext of access may be denying them true access after all. Mandatory placement provides a means to achieve that success, thus providing access to advanced education, a better job, or merely the ability to function and participate more effectively within society.

\section{The Irony of Course Prerequisites for College-Level Courses}

Universities, four-year colleges, and community colleges have no difficulty determining and enforcing prerequisites for college-level courses. No one questions the fact that a student who has never taken a chemistry course and has no knowledge of chemistry should not be allowed to enroll in Organic Chemistry before successfully completing an introductory course. However, for a community college to mandate a certain level of proficiency before students may enroll in college-level courses spurs debate about the fairness of such a practice. Ironically, most institutions nationwide require mandatory placement testing, yet mandatory placement into developmental classes is a step that only some schools are willing to take. According to the National Center for Education Statistic's (NCES) 1989 fall semester survey of college-level remediation which indicates the percentage of four-year colleges mandating placement versus that of community colleges, mandatory placement was more likely to occur in four-year schools than community colleges: $65 \%$ compared to $45 \%$ for remediation in reading; $80 \%$ to $57 \%$ in writing; and $74 \%$ to $51 \%$ in mathematics (Roueche \& Roueche, 1993, p. 144). The most recent figures from the NCES revealed that in 1995, 78\% of higher education institutions offered remedial courses in reading, writing, or mathematics and that three in 10 college freshmen enrolled in a remedial course in both 1989 and 1995 (National 
Center for Education Statistics (NCES) 1998). Clearly, these numbers indicate that the need for remedial or developmental courses continues to exist.

Ironically, once colleges deem students to possess college-level skills, they have no compunction about mandating prerequisites. No one ever introduces the "right to fail" argument at this level because it is not an issue. Yet, colleges hesitate to mandate placement for entry-level college courses-a place that may be the most crucial point for mandatory placement-despite research and reports that indicate the success rate of students who remediate is higher than those students who waive remedial placement and register for college-level courses (Mitchell, 1989; National Association for Developmental Education 1998; Weissman, Silk, \& Bulakowski, 1997). Roueche and Roueche (1993, p. 248) mention what they believe to be the two major causes for the reluctance to require mandatory placement; the ingrained belief that open-door colleges should have no entrance, access, or opportunity barriers and the fear that mandation remediation will reduce enrollments. Perhaps institutions that argue against mandatory placement use the first excuse to hide the second excuse behind, but according to Mitchell (1989) enrollment at Laredo Junior College (Laredo, Texas) actually increased by $25 \%$ after mandatory placement was instituted and students were re-enrolling and persisting at higher rates than before.

\section{The Irony of a Junior-Level Writing Requirement}

Besides the irony of course prerequisites for transfer-level courses, junior-level requirements provide a different type of irony. The University of Colorado-Boulder, the state's flagship institution, mandates a junior-level writing exam. Unlike course prerequisites, such as the previous example of chemistry, students who fail to produce a writing sample meeting the minimum performance standards must enroll in a junior-level writing course. Therefore, despite avoiding the label "remedial" or "developmental," the university has, in effect, a mandatory remedial writing program, which appears to be necessary since only approximately $15 \%$ of the students test out of the junior-level writing course (Nancy Mann, University Writing Program, Telephone Interview, November 1, 1999). Regardless of the rationale, the fact that the University of Colorado-Boulder requires such a writing course acknowledges a responsibility to produce graduates who possess basic writing competencies at a level appropriate for upper-division work. 


\section{The Irony of Performance Indicators in Colorado}

The state legislature is responsible for creating yet another irony related to access versus success. One of the newer performance indicators of the Colorado Commission on Higher Education is graduation rates (Curtin, 1999). Such indicators are consistent with what Ewell and Jones (1991) call the "new accountability," which alters the focus of accountability from equitable access to a return on investment and the emphasis on providing consumers with information about student outcomes and comparative institutional performance (p. 3). It is ironic to think that a single indictor like graduation rate would signify quality, but another irony exists with relation to the position in which it puts community colleges. The pressure to increase graduation rates could produce an adverse effect in the college classroom. Increasingly, some instructors are feeling the pressure to remediate skill deficiencies to help students comprehend what they are teaching, which could result in the unintentional "dummying down" of the course, all to ensure higher graduation rates to meet a state performance standard. But, if students graduate and enroll in a four-year institution where they are unable to perform at the expected level, such results act to reinforce the misperception by some that the community college education is academically substandard. On the other hand, instructors who maintain agreed-upon course objectives and exit skills find that their enrollments decrease as students fail or withdraw from their classes or seek out "easier" instructors who require less work and/or who pass students who perform at a lower level of competency. So, community colleges confront once again the dilemma of access versus standards. Colorado institutions appear to be stuck between a rock and a hard place, with pressure to graduate more students on the one side and the prospect punishment for failing to adequately prepare students on the other. One might again question the ethics of putting community colleges in the position of producing students able to meet certain mandated performance requirements without being able to enforce mandatory placement.

\section{The Irony of a Rising Junior Examination}

Currently in Colorado, the legislature is discussing a plan to institute a rising junior examination to measure institutional accountability as one of over 40 performance indicators the state is considering implementing to evaluate higher education. The idea behind this indicator is to use a nationally normed exam to test English, 
mathematics, science, and critical thinking skills. The state would then provide institutional funding depending on how well those students moving from sophomore to junior levels compare to national norms and against students from various institutions in the state. Although the intent is not to deny access to students based on scores, students would be denied entrance into upper-division courses unless they have taken the exam. With future funding for institutions likely connected in part to this performance indicator, higher education in Colorado will find itself under even more pressure to adhere to course objectives and exit skills, perhaps even altering those objectives to teach to the test. Inevitably this course of action will ensure that the majority of underprepared students who waive remedial placement on entry will fail or withdraw. These were certainly the results for students who waived remedial placement according to the study Weissman, et al., conducted (1997).

Therefore, the irony is that state legislatures and the public are pressuring colleges to be accountable for student learning, which pressures colleges to maintain academic rigor. But, in allowing open access to students who lack the prerequisite skills and placing them into courses taught to ensure academic rigor, community colleges are basically forced to fail those who are underprepared. One might then question how egalitarian community colleges are when they allow this sorting process to occur since the research shows that students who remediate are far more likely to succeed in college than those who skip remediation. Although they do not designate which classes, McMillan, Parke, and Lanning (1997) cite studies by Boylan (1983), Kulik, Kulik, and Schwalb (1983), and Roueche, et al. (1984) and assert that most studies find that "students who successfully complete recommended remedial/developmental courses perform as well as or better than college-prepared students in terms of grade point average, retention, and program completion" (pp. 26-27). Roueche and Roueche (1993) also confirm that students are better served by mandatory assessment and placement (p. 252). Ironically, the egalitarian community colleges, which are not allowed or choose not to implement mandatory placement, become the protectors of the "elite" university system.

One might also question the need for a rising junior examination at all if colleges are allowed to mandate placement, set clear entrance requirements for all college-level courses, and adhere to rigorous academic standards in those college-level courses. In fact, California now allows colleges to implement mandatory placement as long as they follow a set of rigid guidelines created by the Matriculation Regulations Review Task Force in 1993, part of which requires that 
communication or mathematics prerequisites for courses outside of the English and mathematics departments must be based on research demonstrating the applicability of skills in these areas to student success in those courses (Berger, 1997, pp. 36-37). Ironies also extend beyond state policies and mandates to the students themselves.

\section{The Irony of Self-Esteem}

One reason that skill-deficient students often choose to waive remedial placement advice is a perceived loss of self-esteem because of being deficient in certain skills. To enroll in a developmental course may cause the students to appear to be "dumb" in the eyes of their peers. However, they apparently fail to realize that the same situation faces them when they enroll in a college-level course for which they are severely underprepared and will most likely fail or drop, causing them perhaps an even greater loss of self-esteem.

\section{The Irony of the Right to Fail}

Students often believe that they have a right to fail when insisting on waiving placement, which is indicative of yet another irony. Governing agencies and students use the rationale that students are adults and, therefore, should be allowed to make their own choices. If, as a society, we truly believed this to be true, we would allow 18 year olds the right to consume alcohol, and we would abolish all of the so-called "moral laws" (gambling, prostitution, drug use, etc.). Society has a history of stepping in to mandate certain behavior regardless of what some perceive to be a violation of their personal freedoms. In education, if we truly believed that students have the right to fail, then no university or college would have entrance standards. All students would be allowed to enroll and fail in four-year institutions just as they are allowed to do in community colleges. However, in a system which will likely continue to exclude certain students from the four-year institutions because of inadequate academic and skills preparation, the least community colleges should be able to do is establish minimum competency standards for admission into college-level courses.

Community colleges can set entrance standards for certain programs. These standards force students to acquire the necessary basic skills before they can enter the program. Therefore, the precedent is already set to allow students to enroll in community colleges without necessarily being admitted to particular programs. Perhaps, then, the ultimate solution would be to follow what the 
San Diego Community College District has done and establish entrance standards for every course available (Berger, 1997).

Furthermore, a majority of students choose to waive developmental placement (Cohen \& Brawer, 1996, p. 264). Unfortunately, many students waive developmental courses because the courses "fail to count" for anything. Colleges need to do a better job of explaining the value of education, whatever the level, so that students stop perceiving the purpose of going to college as being the earning of grades and credits necessary to obtain a college diploma rather than the acquisition of skills and knowledge. But as Cohen and Brawer point out, when barred from transfer-level courses, students tend to do better (p. 264), so it is in the best interests of students to institute mandatory placement.

Whereas four-year institutions act as gatekeepers, totally barring the underprepared from admission until they prove themselves at an open-admission institution (usually a community college), community colleges are put in the unenviable position of having to fail students who are unable to perform in college-level courses. The primary difference appears to be that four-year institutions close the door to these students while community colleges that permit students to enroll in college-level courses for which they are underprepared have replaced the closed door with the revolving door, to use John Roueche's metaphor. Either way, students fail to gain access to the four-year institution. On the other hand, mandatory placement allows college-level courses to maintain their academic rigor and standards without exposing faculty to the pressures of guilt about being unable to ensure the success of those students who lack the prerequisite skills to produce college-level work at this time. Furthermore, it helps to retain students (Weissman, et al., 1997).

\section{The Irony of Egalitarianism}

Community colleges must also confront the irony that arises from the philosophy they values most: egalitarianism. One might wonder if the real function of community colleges is to weed out the elite for the universities (and for society). By failing students who are unable to perform at a college level, community colleges may be showing students that they truly are not "college material." Under the guise of egalitarianism in the form of open admission and open access to any course, underprepared students are allowed to discover for themselves that their dream of a college diploma is just that-a dream. But hasn't the college performed its own form of elitist selectivity by allowing these students to fail? Perhaps requiring students to sign 
a wavier protects colleges from lawsuits when underprepared students fail, but it appears as if this practice also fails to assume any responsibility for student success. When community colleges knowingly allow students to enroll in courses for which they are underprepared, watch them withdraw from or fail these courses at worst or barely pass with a "C" at best, and ultimately watch them disappear from the college completely, what service have community colleges provided these students or the communities these colleges are supposed to lead?

The National Association of Developmental Education (1998) considers remedial placement waiving a waste of taxpayer dollars. Society prevents 18 year olds from being able to legally purchase alcohol under the assumption that doing so reduces the chances of these young adults from causing physical harm to themselves and/or others. Why would community colleges and those governing boards that control community colleges not stop any adults, young or old, from causing psychological harm to themselves in the form of lowering their self-esteem and sense of self-worth by allowing them to fail? Conversely, what about the effects on the upper 10\% of high school students that community colleges attract? What are the effects of lowering the academic standards-of "dummying down"-in terms of preparing the high achievers to reach their full potential? Perhaps community colleges should examine whether a lowering of standards may compel better students to transfer before reaching graduation.

Is the psychological well-being of people less important than their physical well-being? By allowing students to fail, community colleges are allowing these students to suffer academic harm, which translates into social and economic harm as well. As a society and as a profession guided by our own research, can community colleges afford to allow students to fail if there is a chance that mandatory placement can prevent this? As Van Allen and Belew (1992) contend, "Competitiveness in a global economy, and thus our national welfare, is dependent upon an educated work force and workers armed with basic learning skills" (p. 15). Yet, governing boards appear to ignore the research findings and continue to value open access and freedom of choice over success.

Egalitarianism provides an underpinning of democracy. Mitchell (1989) closes his article by pointing out the paradox of the opportunity of education. To provide the opportunities that education can afford in terms of increased income, better job skills, greater self-esteem, and all the other benefits inherent in a college education, we as educators must assume the responsibility of not giving students "the choice of pursuing an educational track that we know dooms most of them 
to failure. Mandatory remediation and entrance requirements for courses temporarily deny students freedom so that one day they can be truly free"' (p. 18).

\section{The Irony of Context}

One final irony might be termed the irony of context. Our society places such a high value on sports that we have no second thoughts about telling athletes that they are not good enough to make the varsity team or the big leagues. In college, athletes have the opportunity to "walk on" to try out for a team, but they are either cut or not allowed to "suit up" if they lack the ability to perform. One might argue that an underprepared student who "walks on" in an college algebra class, but who is "cut" (fails) is probably no different than the college athlete but with one notable exception-the athlete would still be in school; the student may not. In high school and at some colleges, athletes often have the chance to work at the junior varsity level to improve their skills and their chances of advancing to the varsity team. The minor leagues in some professional sports serve the same function. Is mandatory placement really that much different? Ironically, it appears as if the context makes the difference.

Just as some athletes will quit the sport altogether rather than play on the junior varsity, some students may elect not to enroll in college at all rather than take developmental courses. However, community colleges must question whether such students would withdraw from college anyway once they realize they lack the skills to succeed. The persistence rates of those students who remediate, whether elected or mandated, indicate that developmental courses are more likely to result in students succeeding than failing (Mitchell, 1989; Weissman, et al., 1997). If mandatory placement convinces students not to enroll, how motivated to be in college are they in the first place? By allowing students to make this choice before enrolling in courses, colleges would actually be doing the students, their parents, and the taxpayers a service by preventing the waste of tuition and tax dollars. It would also allow faculty to concentrate their efforts on those students who are truly in college to learn. Finally, knowing that students could not bypass mandatory placement may help high schools with their efforts to graduate students with the necessary competencies.

\section{CONCLUSION}

If the elimination process could occur before students commence to a four-year institution, isn't it preferable to have it occur before the 
money is spent? Saying all this is not to argue that students in developmental courses will not fail or withdraw from school anyway nor to imply that all students whose placement test scores indicate deficiencies will fail if they enroll in college-level courses. Even students with the prerequisite skills to succeed in college-level classes fail or withdraw. But mandatory placement will provide underprepared students with better odds for success (Weissman, et al. 1997). Colleges will still be giving them the choice of how successful they ultimately will be regardless of where they start.

Individual community colleges are already enforcing mandatory placement and are setting prerequisites for entry into college-level courses. This is the case at Laredo Junior College (Mitchell, 1989) and in the San Diego Community College District (Berger, 1997). A 1997 report of community colleges in Michigan indicates an increase has occurred in the number of community colleges mandating assessment and placement since their previous state survey in 1990 (Michigan Developmental Education Consortium, 1997).

Other colleges, like College of Lake County in Illinois, have a mandatory placement policy but allow exemptions. However, the results of their study indicate that students who avoid remediation perform poorly compared to those who remediate. The grade point average of those students who remediated was 2.17 compared to a grade point average of 1.52 for those students who waived placement. Furthermore, students waiving remediation attempted and earned fewer credits and had a lower attempted/earned ratio. Among students who were college-level to begin with, those who remediated also had a higher level of persistence over the measured period of time than did those who waived remediation (Weissman, et al., 1997, p. 192).

Tennessee implemented mandatory remediation in 1985 (Van Allen \& Belew, 1992). Reports from Virginia (Virginia State Board for Community Colleges, 1988) and Massachusetts (Lizotte, 1999) recommend mandatory placement of underprepared students in development courses. One of their 13 essential elements of successful institutional practices for helping at-risk students succeed is "basic skills assessment and placement in appropriate courses should be mandatory" (Roueche \& Roueche, 1993, p. 251). The Southern Regional Education Board also requires students who do not meet minimum standards to take nondegree credit courses/programs that provide further preparation (Spann, Jr. \& McCrimmon, 1994, p. 170). McMillan, et al., (1997) also call for institutional policies to require students to enroll in appropriate coursework (p. 27). However, mandatory placement should not occur without qualifications. "Selective admission into the collegiate programs has been tried again because 
it is easier to screen students out en bloc than to establish criteria for functional literacy course by course. Yet unless those criteria are defined, selective admissions will again be unsuccessful"' (Cohen \& Brawer, 1996, p. 271).

As Berger (1997) points out, in choosing to be prescriptive, colleges must ensure that this intervention "does not block students from access or create discouraging hurdles after enrollment" (pp. 33-34). Unless community colleges take this step of defining entrance competencies and guaranteeing that developmental courses will help students achieve these competencies, they are opening themselves up to the arguments of those who believe that mandatory placement discriminates against students, particularly minorities. Therefore, community colleges nationwide should study policies like those implemented in California, which have strict guidelines for setting course prerequisites. Students must clearly understand skills required in courses so that these prerequisites avoid appearing capricious and unwarranted to enrollment. Furthermore, faculty must ensure that the exit competencies from developmental courses truly match the entrance competencies required in college-level courses so that developmental courses provide a bridge of access to success.

"At least two options are not acceptable: allowing sizable percentages of students to fail, and reducing academic standards so that those who do get through have not been sufficiently well prepared to succeed in the workplace or in further education" (Cohen \& Brawer, 1996, p. 272). To ensure that neither of these options occurs means controlling entrance criteria into college-level classes. Two methods that provide such control affect access: admission standards into the institution itself (in essence doing away with open access) or admission standards into college-level courses (in essence implementing mandatory placement). Perhaps the greatest challenge of postmodern community colleges is finding ways to manage all the ironies that confront them. Despite the criticisms by some that mandatory placement excludes students and restricts their freedoms, it may actually provide the key to open the door to true academic, vocational, or community success.

\section{REFERENCES}

Berger, D. M. (1997). Mandatory assessment and placement: The view from an English department. In A. M. Cohen (Series Ed.) \& J. M. Ignash (Vol. Ed.), New directions for community colleges, no. 100. Implementing effective policies for remedial and developmental education (pp. 33-41). San Francisco: Jossey-Bass. 
Bogart, Q. J. (1994). The community college mission. In G. A. Baker, III (Ed.); J. Dudziak and P. Tyler (Technical Eds.), A handbook on the community college in America: Its history, mission, and management. (pp. 60-73). Westport, CT: Greenwood Press.

Cohen, A. M., \& Brawer, F. B. (1996). The American community college (3rd ed.). San Francisco: Jossey-Bass.

Curtin, D. (1999, October 10). State's colleges face new requisites: 75\% of funds would be tied to performance. The Sunday Denver Post, pp. A1, A18, A19.

Ewell, P. T., \& Jones, D. P. (1991). Assessing and reporting student progress: A response to the "new accountability". Washington, DC: National Center for Education Statistics. (ERIC Document Reproduction Service No. ED 337 112).

Fonte, R. (1997). Structured versus laissez-faire open access: Implementation of a proactive strategy." In A. M. Cohen (Series Ed.) \& J. M. Ignash (Vol. Ed.), New directions for community colleges, no. 100. Implementing effective policies for remedial and developmental education (pp. 43-52). San Francisco: Jossey-Bass.

Lizotte, R. (1999). Access and quality: improving the performance of Massachusetts community college developmental education programs [On-line].

$<$ http://www.necc.mass.edu/mccdec/AccessandQuality2.htm >.

McMillan, V. K., Parke, S. J., \& Lanning, C. A. (1997). Remedial/developmental education approaches for the current community college environment. In A. M. Cohen (Series Ed.) \& J. M. Ignash (Vol. Ed.), New directions for community colleges, no. 100. Implementing effective policies for remedial and developmental education (pp. 21-32). San Francisco: Jossey-Bass.

Mitchell, T. R. (1989). Daring to demand: Mandatory remediation works! Paper presented to the faculty of St. Philip's Community College. (ERIC Document Reproduction Service No. ED 305 117).

Need for mandatory academic testing and placement of students in appropriate college courses. Resolution Approved March 1, 1998 by NADE Executive Board, Revised July 31, 1998 [On-line]. National Association for Developmental Education. $<$ http://www.umkc.edu/cad/nade/nadedocs\&sol;pstsp198.htm>.

Rhoads, R. A., \& Valadez, J. R. (1996). Democracy, multiculturalism, and the community college: A critical perspective. New York: Garland Publishing, Inc.

Roueche, J. E., Baker, G. E., \& Roueche, S. D. (1984). College responses to low-achieving students. New York: Harcourt, Brace, \& Jovanovich.

Roueche, J. E., \& Roueche, S. D. (1993). Between a rock and a hard place: The at-risk student in the open-door college. Washington, DC: American Association of Community Colleges.

Spann, Jr., M. G., \& McCrimmon, S. (1994). Remedial/developmental education: Past, present, and future. In G. A. Baker, III (Ed.); J. Dudziak and P. Tyler (Technical Eds.), A handbook on the community college in America: Its history, mission, and management. (pp. 161-175). Westport, CT: Greenwood Press.

A survey of student academic assessment and developmental education services in Michigan's public community colleges: Third state survey-executive summary. (1997). Michigan Department of Education, Michigan Developmental Education Consortium, Michigan State Board for Public Community Colleges.

$<$ http://www.mccnet.educ.msu.edu/ccinfo/execsum.html $>$.

U.S. Department of Education, National Center for Education Statistics. (1998). Remedial education in higher education institutions. The condition of education 1998, Indicator 28. <http://nces.ed.gov/pubs98/condition98/c9828a01.html>.

Van Allen, G. H., \& Belew, V. S. (1992). Mandatory remediation in Tennessee: Strategy for promoting excellence while serving the underprepared. (ERIC Document Reproduction Service No. ED 353 015). 
Virginia State Board for Community Colleges and Virginia State Council of Higher Education. (1988). Report of the state council of higher education/Virginia community college system joint task force on remediation. (ERIC Document Reproduction Service No. ED 290 518).

Weissman, J., Silk, E., \& Bulakowski, C. (1997). Assessing developmental education policies. Research in Higher Education, 38.2, 187-200.

Zhou, D., \& Voorhees, R. A. (1999). A profile of basic skills education students at CCCOES. Educational Support Services Colorado Community College and Occupational Education System. 
Copyright $\odot 2003$ EBSCO Publishing 